\title{
Number of Live Fetuses
}

National Cancer Institute

\section{Source}

National Cancer Institute. Number of Live Fetuses. NCI Thesaurus. Code C124624.

A measurement of the number of live fetuses in the uterus. 